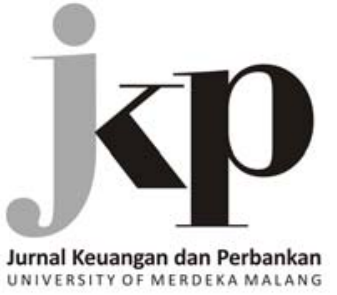

Article history:

Received: 2019-03-11

Revised: 2019-05-05

Accepted: 2019-06-26

Keywords:

Government bond; Order flow; Private information

JEL Classification: G12, G14, G11

Kata kunci:

Obligasi negara; Order flow; Informasi privat

$\triangle$ Corresponding Author:

Buddi Wibowo:

Tel. +62 217270164

E-mail: buddi.wibowo@ui.ac.id

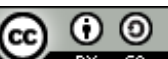

This is an open access

article under the CC-BY-SA license

\section{Private information, yield volatility, and interaction between groups of investors: Case of Indonesia government bond market}

\author{
Buddi Wibowo \\ Department of Management, Faculty of Economics and Business, Universitas Indonesia \\ Jl. Prof. Dr. Sumitro Djojohadikusumo Kampus UI, Depok, 16424, Indonesia
}

\begin{abstract}
Relation of private information and yield volatility in the relatively low liquid market such as Indonesia government bond market is one of the recent important research topics in finance. Because private information accumulation mastery affects interaction pattern between dealers and their customers, it is urgent to identify this price mechanism in government bond market, especially in a low liquid market which small trading volume may create serious yield volatility. If there is a substantial disagreement on bond fair value because of distinct private information quality between each those groups of investors success to accumulate it, bond price will fluctuate wildly. This paper study the dealer and customer order flow interaction to identify which side that have a greater impact on yield volatility. The results show that from the two layers of order flow, disagreement between dealers and customers are slightly in a short-term and medium-term bond, so their volatility is relatively low. But for a long-term bond, disagreement is substantial and creates high yield volatility. Different trading platform and strategy between dealer and customer play an important role in creating high yield fluctuations.
\end{abstract}

\begin{abstract}
Abstrak
Hubungan antara informasi privat dan volatilitas imbal hasil obligasi di pasar yang memiliki likuiditas yang rendah seperti pasar obligasi pemerintah Indonesia merupakan topik riset baru di bidang keuangan. Karena perbedaan kemampuan akumulasi informasi privat mempengaruhi interaksi antara dealer dan customer, sangat mendesak untuk dapat mengidentifikasi mekanisme harga di dalam pasar obligasi pemerintah, khususnya pada pasar yang likuiditasnya rendah dimana volume perdagangan yang kecil sekalipun dapat menyebabkan perubahan harga yang besar. Jika ada ketidaksetujuan yang substantial atas harga wajar obligasi karena perbedaan kualitas informasi privat yang dimiliki setiap kelompok investor tersebut, harga pasar obligasi akan berfluktuasi sangat tinggi. Riset ini mempelajari interaksi order flow dari dealer dan customer untuk dapat mengidentifikasi mana dari dua kelompok itu yang memiliki dampak yang lebih besar terhadap volatilitas imbal hasil. Hasil penelitian ini menunjukkan adanya sedikit ketidaksepakatan antara dealer dan customer dalam perdagangan periode jangka pendek dan menengah sehingga volatilitas imbal hasil relatif rendah pada dua jangka waktu itu. Namun dalam jangka panjang, ketidaksepakatan itu sangat substantial sehingga volatilitas jangka panjang relatif tinggi. Perbedaan platform perdagangan dan strategi antara dealer dan customer menyebabkan fluktuasi imbal hasil yang tinggi.
\end{abstract}

How to Cite: Wibowo, B. (2019). Private information, yield volatility, and interaction between groups of investors: Case of Indonesia government bond market. Jurnal Keuangan dan Perbankan, 23(2), 167-179. https:/ / doi.org/10.26905/ jkdp.v23i2.2823 


\section{Introduction}

Price discovery in financial markets is very an important property, especially in the perspective of market microstructure (Martinez \& Tse, 2018; Kryzanowski, Perrakis, \& Zhong, 2017). Price discovery plays a very important and specific role in financial markets. (O'Hara, 2003) states that price discovery is one of two important main functions of the financial market, firstly financial market function is the liquidity provider for all market participants and secondly, the market serves a price discovery, namely the place or media for the creation of financial securities price.

Some market microstructure literature propose various definitions of price discovery, among others: "price equilibrium search process" (Schreiber \& Schwartz, 2009), "collection and interpretation of news" (Baillie, Booth, Tse, \& Zabotina, 2002), "process incorporation of implicit information in investors' trading into market prices" (Lehmann, 2002)," a mechanism for changes in the yield curve which is a combination of heterogeneous private information and/or interpretation of public information through trades in the bond market " (Brandt \& Kavajecz, 2004), "The merger of two information channels, namely direct information channels where prices adjust quickly to public information and indirect channels where prices adjust to private information reflected in order flow" (Valseth, 2013) and "unification of information at the right time into market prices" (Caporale \& Girardi, 2013). We may conclude that price discovery is a naturally occurring dynamic process of market prices creation through rapid price adjustments from the old equilibrium price to the new equilibrium price which is driven by and because of the presence of a series of information, both public information and private information.

From the practitioner's point of views, price discovery conception is very urgent also because it not only helps investors to make more informed decisions but also facilitates better risk management.
Investors who understand the mechanism by which information is translated into market prices and the factors that influence them will certainly have a better trading strategy (Westerlund, Norkute, \& Narayan, 2015).

Empirical research on price discovery and price formation in several financial markets can be found in, mentioning only a few, Hasbrouck (1991); Evans \& Lyons (2002), Brandt \& Kavajecz (2004) who all find that contemporary order flow explains the most of the daily price changes that occur in the stock market, the foreign exchange market, and the United States government bond market. Order flow is a measurement of net buy pressure that occurs in the bond market. Valseth (2013) calculates order flow by reducing trade initiated by sellers from trade initiated by buyers during a certain time interval. Buyer initiated trades are assigned a positive sign while the trade initiated by the seller is assigned a negative sign.

Market microstructure studies of price discovery attempt to reveal whether private information plays an important role in price formation (CollinDufresne \& Fos, 2015). If private information plays an important role in price discovery, prices are not formed instantaneously based on mere public information, but price discovery is formed from a process or mechanism of information collection and processing (Khalil, Mansi, Mazboudi, \& Zhang, 2019). The price discovery describes the process of how relevant information about financial securities is transformed into the security price.

In the price discovery of government bonds, information plays a very important role where this information is divided into two major parts: public information and private information. Evans \& Lyons (2002) define private information is type of information that is not known to all parties, except certain parties who have an excellent, above on average, analytical skills and can obtain important information by paying a sum of money or having a special connection with sources of information, 


\section{Private information, yield volatility, and interaction between groups of investors...}

Buddi Wibowo

specifically that can make better price forecasting than just relying on public information (CollinDufresne \& Fos, 2015). Whereas Brandt \& Kavajecz (2004) state that private information is an interpretation of public information on how the yield curve changes. Periodic price adjustments through order flow imply that prices do not fully reflect all information at the time and show that there is asymmetric information from market participants (Cieslak \& Povala, 2016).

In the government bond market, according to. Valseth (2013), private information can be divided into two dimensions, as follows: (1) the first dimension of private information includes fundamental and non-fundamental information. Fundamental information is related to macroeconomic factors, heterogeneous interpretations of macroeconomic indicators. (2) The second dimension of private information is the source from which the information originates.

There are two sources of information, first, the ability of the second dealer interpreting all available information, and the second source is the customer trading data which reflect information owned by customers.

Dealer ability is the ability to obtain and interpret relevant information, including interpretation of public information and information that can be translated from other dealer order flow and customer order flows. If the information in an order flow occurs among dealers only reflects or is exactly same as the information which can be extracted from the customer's order flow, it indicates that the dealer does not add any information to the trade or they have no substantial private information. In such conditions, the dealer only acts as a passive mediator of the customer order (He, Kelly, \& Manela, 2017). Whereas if the order flow among dealers is more informative than customer order flow, it indicates that the dealer has more information than their customers. Anand \& Subrahmanyam (2008) find that dealers have contributed more to price discovery than customers and concluded that dealers were more informed than other market participants. In the equity market, insider information relating to company earnings or company mergers maybe a third source of information, but this type of information is not relevant to the government bond market.

Valseth (2013) find trades carried out by all investor groups other than the dealers (customers) is far less informative than the transaction executed by fellow dealers (interdealer market). Explanatory power from an interdealer order flow is far greater than a customer order flow, which shows that the dealers have better information than the customers. However, customers also have a significant price impact, so their order drive significant price change, but the impact far lower compared to the dealers. This indicates that some dealers have the ability to identify information from the trading patterns of their customers.

At the dealer level, the results of Valseth (2013) study show that the quality of dealer information mastery is heterogeneous and contributes differently to the process of price discovery. Order flow from large dealers (measured by their market share) has the greatest influence. Interdealer order flow from the two largest dealers has the biggest influence on prices on 4-year and 7-year bonds, as well as the order flow of the four largest dealers that has the biggest effect on the price of 10-year bonds. Order flows in government bonds which have different maturity have different effects on prices depends on the type of dealer. Valseth (2013) found that order flows from a group of dealers have a strong impact on prices on bonds with short tenors, while other groups of dealers have order flows that have a major impact on bonds with short tenors. This indicates that the dealer specializes in different trading segments.

The results of many previous research which focus at the dealer level also show that the correlation between customer order flow and interdealer 
order flow varies among dealers. There are dealers who resemble their customers' order flow which they believe reflect customers' private information, on the other hand, there are dealers who have independent and unique order flow because they follow their specific private information and subjective interpretation on public information. Quality of information embedded in order flow differs among investors because of their individual competency, beliefs, and their access to sources of information (Anand \& Subrahmanyam, 2008; Valseth, 2013). Different information content in dealer and customer order flow will be captured in yield fluctuations along the period. Disagreement among investor in the same group (dealer or customer) and/ or disagreement between dealer groups and customer groups create a different market position for each investor and make yield swing from one extreme position to other extremes ( $\mathrm{O}^{\prime}$ Hara, 2003)

Each investor's peculiar investment horizon drives to a different information set. Different information creates a different trading position in the market (Back, Crotty, \& Li, 2018). There are many research which investigates how price discovery process affects bond yield volatility. Because of asymmetric information among market agent and nonsynchronous information arrival time for each investor, there is a substantial difference in market position among a group of investors. For example, Nowak et al. (2011) find two types of adjustment which are, firstly, repricing, or what is called as the price impact and, secondly, repositioning, or the volatility impact. The price impact is a permanent change in asset prices as an investor find a change of the fair value of a bond. If investors disagree on the fair value of a bond, they reposition their own bond portfolio based on their own information set. Different information set and timely arrival of the information among investors swing the bond yield.

Valseth (2013) has the excellence of empirical method in testing information set difference between investor groups because he uses two types of order flow: customer and dealer order flow shows the customer order flow is an important part of the flow orders of some dealers who have a significant impact on prices. But Valseth (2013) also found that the order flow of the customer does not always correlate with the flow order in the interdealer market but also have a large influence on prices. This shows that some dealers have additional information learned from their customer orders and other private information that they collect themselves. The findings in this study indicate that dealers play an important and independent role in the price discovery process.

If there is disagreement among investor about the fair value of a bond, price volatility will be high. The disagreement creates a dispersed bid and offer price among investors and drives high trading price volatility (Ma, Wang, Cheng, \& Hu, 2017). Disagreement among investor come from different quality of private information among investors and the quality of their interpretation of public information (Condie \& Ganguli, 2017). If there is a dominant player in the market, for example, dealer order flows are very high, but on the other hand, customer order flows are trivial, the disagreement would have low price impact. We assume disagreement among dealers is trivial because of similar ability and knowledge among them.

There are many studies which investigate the relation of prices and volatility to public information, e.g., Andersen, Bollerslev, Diebold, \& Vega (2007), Brenner, Pasquariello, \& Subrahmanyam (2009), and Kang, Ratti, \& Yoon (2015). They document the relationship between public information and price volatility in equity, foreign exchange, and Treasury markets. Other research reveal price fluctuation and private information relations which are reflected in trading volume and frequency, for equity (Albuquerque \& Vega (2009); Hasbrouck (1991), foreign exchange (Evans \& Lyons, 2008), and treasury markets (Brandt \& Kavajecz, 2004; Menkveld, Sarkar, \& Van Der Wel, 2012). These studies use order flow as the measure of private information which is extracted from the trading process. Berger, 


\section{Private information, yield volatility, and interaction between groups of investors...}

Buddi Wibowo

Chaboud, \& Hjalmarsson (2009) find variation in volatility can be explained by variation in information flow. Evans \& Lyons (2008) show a correlation between unconditional volatility and order flow.

The objective of this paper is to examine the role of different market participants in the process of price discovery in the Indonesian government bond market, which has a specific characteristic that its liquidity is relatively low. This paper has an important contribution because previous research focuses on the developed market, which is a liquid market (Bongaerts, De Jong, \& Driessen, 2017). This paper also identifies the interaction pattern between investor groups and their impact on yield volatility. Effect of private information executed by a group of investors will be very substantial in low liquid market. The Indonesian government bond market is characterized by a two-tier structure, which reflects customer's trade with dealers, while dealers can trade either with their customers or with other dealers. The specific objectives of this study are (1) is price discovery driven by the interdealer market or customer market, (2) the role of dealers and customers in price volatility whether they have a similar impact in each type of government bond with a different tenor.

\section{Hypotheses Development}

Different ability among investors to accumulate private information and to interpret it as an effective investment strategy creates a dispersed bid and offer prices and push yield volatility up (Brandt \& Kavajecz, 2004). The disagreement between groups of government bond investor, dealers, and their customers also drives higher yield volatility (Nowak, 2011). The disagreement between dealers and customers is reflected in their trading behavior, especially in their order flow (Menkveld, Sarkar, \& Van Der Wel, 2012). Active trading and imminent impact of order flow on yield is a signal of execution of private information. If dealer order flow and customer order flow simultaneously have an imminent and significant impact on yield volatility, then we may conclude that there is a severe disagreement between dealers and customers, they react differently based on different private information or have a distinct interpretation on the same information.

Because of the different quality of information between investor groups (customer and dealer), investors rebalance their portfolios when information arrives, and they reposition their portfolio according to their risk preferences and investment horizon. Disagreement among customer and dealer and different investment horizon will affect and create significant yield volatility. As previous research do, such as Nowak et al. (2011) and Brandt \& Kavajecz (2004), uninformed investors usually trade based on public news announcement that naturally they consider short term information. We hypothesize that short term customer order flow tend to have a significant impact on bond yield volatility. The volatility will be lower if the dealer tries to exploit customer trading pattern and get profit on the customer by taking the opposite position compared to their customer. Customer position on long term and medium-term bond will be affected by relevant long and medium-term expectation, not only by changes of short term information. Longerterm bond yield volatility will be affected by many other variables other than recent order flow that maybe are not included in the model.

Because of specific government bond characteristic which usually has a relatively huge market value, compared to stock, active trading happens in the initial period aftermarket auction which only dealers are permitted to deliver the order. In the initial period, customers who are interested in getting the bond, delivering a buying order to dealers. If there is a disagreement among investors, especially between dealers and customers, the long-term bond will have the highest yield volatility Kang, Ratti, \& Yoon (2015). This volatility may come from long-term order which indicates different beliefs among investors in future the bond prospect and 
long-term macroeconomic forecasting and/or different short-term liquidity preference and shortterm investment strategy (Brenner, Pasquariello, \& Subrahmanyam, 2009).

\section{Method, Data, and Analysis}

We use the government bond transaction data from Directorate General of Financing and Risk Management, the Ministry of Finance, Republic of Indonesia. Changes in bond yields were obtained from Thomson-Reuters Datastream. Data from this study were from January 2009 to 2016

The following model is used to compare the impact of aggregate interdealer order flow and aggregate order flow customers on price volatility in the Indonesian government bond market:

$$
\begin{aligned}
\operatorname{VolY}_{t}^{i}= & c+\beta_{1} O F_{t}^{S}+\beta_{2} O F_{t}^{M}+\beta_{3} O F_{t}^{L}+\beta_{4} C O F_{t}^{S}+ \\
& \beta_{5} C O F_{t}^{M}+\beta_{6} C O F_{t}^{L}+e_{t}
\end{aligned}
$$

Where $\operatorname{Vol} Y_{t}^{i}$ is daily yield-volatility; $i=3,5$, and 10 year until bond maturity date; $c$ is a constant, $O F_{t}^{S}, O F_{t}^{M}$ and $O F_{t}^{L}$ are, in sequence, aggregate interdealer order flow Short term (S); Medium term (M) and Long term (L); $C O F_{t}^{S}, C^{2} F_{t}^{M}$ and $C O F_{t}^{L}$ are aggregate customer order flow.

To measure yield volatility, we use $A R(q)$ GARCH $(1,1)$

$$
\begin{aligned}
& y_{t}=a_{0}+\sum_{i=1}^{q} a_{i} y_{t-i}+\varepsilon_{t} \\
& \sigma_{t}^{2}=a_{0}+\beta_{1} \sigma_{t-1}^{2}+\beta_{2} \varepsilon_{t-1}^{2}+\varepsilon_{t}
\end{aligned}
$$

So our empirical model are:

$$
\begin{aligned}
\operatorname{VolY}_{t}^{3}= & c+\beta_{1} O F_{t}^{S}+\beta_{2} O F_{t}^{M}+\beta_{3} O F_{t}^{L}+\beta_{4} \operatorname{COF}_{t}^{S}+ \\
& \beta_{5} \operatorname{COF}_{t}^{M}+\beta_{6} \operatorname{COF}_{t}^{L}+e_{t} \\
\operatorname{VolY}_{t}^{5}= & c+\beta_{1} O F_{t}^{S}+\beta_{2} O F_{t}^{M}+\beta_{3} O F_{t}^{L}+\beta_{4} \operatorname{COF}_{t}^{S}+ \\
& \beta_{5} \operatorname{COF}_{t}^{M}+\beta_{6} \operatorname{COF}_{t}^{L}+e_{t}
\end{aligned}
$$

$$
\begin{aligned}
\operatorname{VolY}_{t}^{10}= & c+\beta_{1} O F_{t}^{S}+\beta_{2} O F_{t}^{M}+\beta_{3} O F_{t}^{L}+\beta_{4} C O F_{t}^{S}+ \\
& \beta_{5} C_{O F}^{M}+\beta_{6} C O F_{t}^{L}+e_{t}
\end{aligned}
$$

In order to measure daily order flow impact on the yield volatility, data on daily changes of the 3-year, 5-year and 10-year Government bond yield are analyzed. This yield is based on the price at the end of the trading day. Order flow is divided into three maturity groups. The first is a short-term order flow that contains bonds that have 12-36 months maturity. Second, medium-term flow orders that contain bonds that have a remaining time of 36-60 months due. Third, long-term flow orders that contain bonds that have the maturity for more than 60 months. Three groups due to order flow interdealer are labeled with OFS, OFM, and OFL, and groups of customer order flow are labeled COFS, COFM, and COFL.

How to test the hypothesis of whether dealers and customer have private information and use it as a driver to implement their investment strategy, we can look at F-test and t-test for each equation. If F-test shows all order flow significantly affect yield volatility, we may conclude dealer and customer have private information, and they have a different interpretation on public information. If dealer order significantly affects yield volatility, we may conclude that there are disagreements among dealers because the dealers have different private information. If customer order significantly affects yield volatility and dealer order does not, we may conclude customers disagree about private information and interpretation on public information and dealer play only as a trading intermediator.

\section{Results}

The author needs to report the results in sufficient detail so that the reader can see which statistical analysis was conducted and why, and later to justify their conclusions. 


\section{Private information, yield volatility, and interaction between groups of investors...}

Buddi Wibowo

Descriptive statistics in Table 1 show changes in the daily yield of bonds with the remaining 10year tenor is the largest average among Indonesia government bond for all categories of maturity. While the maximum value of yield changes occurs in 5-year medium-term bonds and the lowest yield changes occur in short-term 3-year bonds. The highest volatility, represented by standard deviation, occurs in changes of 10-year long-term bonds yield. The descriptive data show as the maturity period approaches, bond yields tend to be more stable, while at the beginning of the issuance, transactions in the market are still looking for a price balance so that price volatility is quite high.

Table 1. Descriptive statistics of yield

\begin{tabular}{lrrr}
\hline & YC_3Y & YC_5Y & YC_10Y \\
\hline Mean & -0.201 & -0.231 & -0.293 \\
Median & -0.611 & -0.401 & -0.501 \\
Maximum & 63.400 & 67.000 & 58.500 \\
Minimum & -77.191 & -73.115 & -50.317 \\
Std. Dev. & 9.517 & 8.957 & 10.193 \\
Skewness & 0.355 & 0.377 & 0.688 \\
Kurtosis & 15.765 & 14.513 & 9.005 \\
Jarque-Bera & 935.00 & 882.19 & 333.87 \\
Prob. & 0.000 & 0.000 & 0.000 \\
Observations & 1600 & 1600 & 1600 \\
\hline
\end{tabular}

Source: Ministry of Finance Republic of Indonesia

Table 1 shows the long-term customer order flow (CFOL) has the largest average among all categories of order flow of government bonds which reinforces indications of high trade-in bonds with the remaining long tenor as can be found in Table 1 . The order flow from the dealer is also the most many are in the Long-term dealer order flow (OFL). But the highest maximum value actually occurs in shortterm customer flow orders. This indicates that the shortest tenor bonds have large transactions which were executed by few customers. Some bond investors focus on bond transactions that are almost due because they target the payment of the principal debt at maturity and are supported by stable bond prices ahead of maturity.
Table 2 presents the volatility estimation using GARCH $(1,1)$. We find time-varying variance GARCH $(1,1)$ estimation as:

$$
\begin{aligned}
& y_{t}=0.35+0.83 y_{t-1}+\varepsilon_{t} \\
& \sigma_{t}^{2}=0.26+0.37 \sigma_{t-1}^{2}+0.28 \varepsilon_{t-1}^{2}+\varepsilon_{t}
\end{aligned}
$$

Table 2. Yield volatility

\begin{tabular}{lccc}
\hline & Vol_3Y & Vol_5Y & Vol_10Y \\
\hline Mean & 0.18 & 0.30 & 0.34 \\
Median & 0.27 & 0.44 & 0.31 \\
Maximum & 0.23 & 0.45 & 0.38 \\
Minimum & 0.18 & 0.25 & 0.14 \\
\hline
\end{tabular}

Source: Ministry of Finance Republic of Indonesia

Yield volatility of long-term bond (Vol_10Y) is the highest. On the run bond, which is recently issued a bond and has long remaining time to maturity, has a unique characteristic. On the run bond trading, volume and price volatility are usually high because all market participant tries to rebalance their portfolio and include this on the run bond into a new investment portfolio. Fair price, also its yield, is still in the process to reach its market equilibrium (Menkveld, Sarkar, \& Van Der Wel, 2012). Bond yield volatility decreases monotonically from long-term bond to medium-term and short-term bond. This property indicates approaching its maturity; investors reach an agreement on fair bond value, and bond price gradually reaches its equilibrium.

\section{Short-term bond Regression Analysis}

Table 3 shows regression analysis on government bonds with short-term maturities, which is bond with remaining time to maturities of one year to three years.

Based on the regression analysis, we find only OFS has significant value $(5 \%)$ and the other variables do not have a significant effect on yield volatility. This means only short-term order dealer flow from interdealer trades that contribute to daily yield 
fluctuation. However, the probability value (F-Statistic) 0.017 is smaller than $\alpha$ (level of error $5 \%$ ) which means that all order flows both dealers and customers at all maturities simultaneously have a significant effect on yield volatility of short-term bonds. Regression coefficients show an increase of 1unit dealer order flow will increase the daily yield of short-term government bonds 0.275 bps. These results indicate that dealers have a large role in the process of price discovery that occurs in the government bond market with a maturity of one to three years. This result is similar to the Valseth (2013) that dealer order flow in government bond markets plays an important role in price discovery.

Yield volatility of government bond approaching maturity is driven by dealers' and customers' shortterm order flow. However, short-term bond yield volatilities are mainly influenced by transactions in the interdealer market (OFS) which has higher coefficient magnitude and more significant compared to customer order flow (COFS) even though the value of trade transactions carried out by other groups of investors (customer) is much higher than the interdealer market. This clearly shows dealers have superior private information compared to their customers. Slightly disagreement between dealers and their customers drive low short-term bond yield volatility.

\section{Medium-term bond Regression Analysis}

Table 4 shows regression analysis on government bonds with medium-term maturities, which is bond with remaining time to maturities between three years to five years.

Table 3. Short-term bond Regression Analysis

$\operatorname{VolY}_{t}^{3}=c+\beta_{1} O F_{t}^{S}+\beta_{2} O F_{t}^{M}+\beta_{3} O F_{t}^{L}+\beta_{4} C O F_{t}^{S}+\beta_{5} C O F_{t}^{M}+\beta_{6} C O F_{t}^{L}+e_{t}$

\begin{tabular}{lcccc}
\hline \multicolumn{1}{c}{ Variable } & Coefficient & Std. Error & t-Statistic & Prob. \\
\hline OFS & 0.275 & 0.081 & 2.295 & 0.018 \\
OFM & -0.097 & 0.078 & -1.567 & 0.376 \\
OFL & -0.123 & 0.064 & -1.210 & 0.137 \\
COFS & 0.110 & 0.005 & 0.536 & 0.035 \\
COFM & 0.069 & 0.099 & 0.689 & 0.491 \\
COFL & -0.198 & 0.104 & -1.543 & 0.138 \\
C & 1.472 & 0.377 & 3.665 & 0.001 \\
\hline R-squared & & & & 0.87 \\
Adjusted R-squared & & & & 0.80 \\
F-statistic & & & & 3.431 \\
Prob (F-statistic) & & & & 0.017 \\
\hline
\end{tabular}

Table 4. Medium-term bond Regression Analysis $\operatorname{VolY}_{t}^{5}=c+\beta_{1} O F_{t}^{S}+\beta_{2} O F_{t}^{M}+\beta_{3} O F_{t}^{L}+\beta_{4} C O F_{t}^{S}+\beta_{5} C O F_{t}^{M}+\beta_{6} C O F_{t}^{L}+e_{t}$

\begin{tabular}{lcccc}
\hline \multicolumn{1}{c}{ Variable } & Coefficient & Std. Error & t-Statistic & Prob. \\
\hline OFS & 0.071 & 0.089 & 0.888 & 0.383 \\
OFM & 0.013 & 0.087 & 0.219 & 0.837 \\
OFL & 0.043 & 0.077 & 0.555 & 0.566 \\
COFS & 0.219 & 0.101 & 2.155 & 0.031 \\
COFM & -0.089 & 0.105 & -0.849 & 0.396 \\
COFL & -0.111 & 0.111 & -1.333 & 0.114 \\
C & 1.587 & 0.430 & 2.388 & 0.014 \\
\hline R-squared & & & & 0.825 \\
Adjusted R-squared & & & & 0.819 \\
F-statistic & & & & 1.769 \\
Prob. (F-statistic) & & & & 0.132 \\
\hline
\end{tabular}


Based on the results of the regression analysis, we may conclude that COFS has significant value (5\%) and other variables do not have a significant effect on bond yield volatility (VolYC_5Y). This means only short-term customer order flow that contributes to daily yield volatility. The probability value of F-statistics is 1,769 greater than $\alpha$ means that both dealer order flow, and customer order flow simultaneously do not affect the medium-term bond yield volatility. We may guess there are other variables such as macroeconomic variable, liquidity, and investor sentiment that affect the volatility which is not included in the model. This is open to further examination for the next research. The regression coefficient shows that if customer order flow increases 1 unit, daily medium-term government bonds yield volatility will increase 2,19 bps. This result shows the only customer has a role in the process of price discovery of bond yield volatility with remaining time to maturity threeyears to five years. This result is not similar to the results of the Valseth (2013) study which find precisely the dealer order flow, not the customer, had a significant effect on the price discovery in the government bond market with medium-term maturity. But this shows that in the Indonesian government bond market, the medium-term bond has a unique empirical fact where customers are informed customers or investors who have short-term private information that has far better quality than dealers' private information.
These results indicate that the customer has a significant and major role in the process of price discovery in the Indonesia government bond market, especially bond with remaining time to maturity five years to ten years, but the superiority of customer information is only on short-term information so that only short-term order flow is significant. This shows customers have better private information accumulation compared to dealers in short-term trading of government bonds. Customers make transactions for short-term interests only so that only short-term order flow is significant. Customers conduct short-term transactions, presumably only utilizing transitory market liquidity conditions or driven by incidental needs of other customers who need immediate cash so that prices only increase in a short period. This is in accordance with the conditions of the Indonesian government bonds which are relatively less liquid. Customers' dominance in medium-term government bond trading drives low medium-term bond yield volatility. The disagreement between customers and dealer is not present in medium-term bond trading because of low and insignificant dealers order flow of this type of bond.

\section{Long-term bond Regression Analysis}

Table 5 shows regression analysis on government bonds with medium-term maturities, which is bond with remaining time to maturities more than five years.

Table 5. Long-term bond Regression Analysis

\begin{tabular}{lcccc} 
OolY $_{t}^{10}=c+\beta_{1} O F_{t}^{S}+\beta_{2} O F_{t}^{M}+\beta_{3} O F_{t}^{L}+\beta_{4} \mathrm{COF}_{t}^{S}+\beta_{5} \mathrm{COF}_{t}^{M}+\beta_{6} \mathrm{COF}_{t}^{L}+e_{t}$ & & t-Statistic & Prob. \\
\hline \multicolumn{1}{c}{ Variable } & Coefficient & Std. Error & -1.318 & 0.119 \\
\hline OFS & -0.117 & 0.086 & 1.135 & 0.644 \\
OFM & 0.405 & 0.075 & 0.864 & 0.031 \\
OFL & 0.365 & 0.089 & 3.965 & 0.018 \\
COFS & 0.338 & 0.170 & -1.059 & 0.301 \\
COFM & -0.119 & 0.131 & -2.439 & 0.051 \\
COFL & -0.082 & 0.151 & 1.574 & 0.115 \\
C & 0.317 & 0.523 & & 0.827 \\
\hline R-squared & & & & 0.813 \\
Adjusted R-squared & & & & 1.868 \\
F-statistic & & & & 0.107 \\
Prob (F-statistic) & & & & \\
\hline
\end{tabular}


Based on the results of the regression analysis presented in Table 5, we find COFS and OFL has significant value (5 percent) against VolYC_10Y and other variables do not have a significant effect. This result shows short-term customer order flow, and long-term order flow contribute to daily long-term bond yield volatility. The magnitude of regression coefficients for long-term bond yield volatility is higher than medium-term bond yield volatility. It shows an increase of 1 customer order flow will increase 0.338 bps daily long-term government bond yield volatility. These results indicate that the customer has a significant and major role in the process of price discovery in the bond market, especially bond with remaining time to maturity longer than ten years, but the superiority of customer information is only on short-term information so that only short-term order flow is significant. This shows customers have better short-term private information accumulation compared to dealers in short-term trading of long-term government bonds. However, dealers have a significant effect on long-term bond yield volatility for long-term trading. Dealers have superior long-term information and analysis, implement a strategic investment portfolio, because they have a long investment horizon. The disagreement between customers and dealer, even though in the different investing time horizon, creates dispersed bid prices in the market and drives high yield volatility. Long-term bond has the highest volatility compared to short and medium-term bond.

\section{Discussion}

In the Indonesian government bond market, the order flow has a significant effect on bond yield volatility, where short-term customer order flows have a significant impact on short and medium-bond yield volatility. This shows that there is such an informed customer. This finding is different from Valseth (2013) who find only dealer order flow that has a strong influence on the price formation in the Norwegian government bond market. This can show that in the Indonesian government bond trade, the customer does not only trade based on liquidity considerations but has information in making decisions or making investment portfolios, especially in the short-term and medium bond.

Bond yield volatility is mainly influenced by disagreement between a group of investors which are between dealers and customers. Highest volatility is found in a long-term bond which customers' short-term trading and dealers' long-term trading creates a dispersed bid and offer price in the market. Customers trade based on short-term information which is, for examples, short-term market liquidity, customer-risk preference adjustments because of short-term macroeconomic data announcements, and economic bubbles driven by customers' behavioral overshoot or overreaction (Bartolini, Goldberg, \& Sacarny (2008); Brenner, Pasquariello, \& Subrahmanyam (2009). On the other hand, dealers who have long investment horizon, trade only because of bond intrinsic value. Bond yield changes in the short-term period do not drive more active dealer order flow. The different trading pattern between dealers and customers in longterm bond creates high yield volatility (Menkveld, Sarkar, \& Van Der Wel, 2012).

The Indonesian government bond market, which is relatively less liquid than developed bond markets, has unique empirical facts, that dealer order flow has a significant effect only on long-term bond yields. This means that dealers influence the formation of long-term bond prices, while in medium and long-term bonds more influenced by customer order flow. This also shows that customers prefer to trade or invest in bonds that have a relatively short maturity and exploit their short-term private information in their trading activities. Market fragmentation between dealers and customer make different private information and disagreement between these group of investors a substantial effect on yield volatility (Caporale \& Girardi, 2013). Disagreement among customers has a stronger effect. 


\section{Private information, yield volatility, and interaction between groups of investors... \\ Buddi Wibowo}

\section{Conclusion, Limitations, and Suggestions Conclusion}

Indonesia government bond market has a unique characteristic which dealer order flow only has a significant effect on long-term bond yield volatility. Because of lower liquidity and narrow investor base, customer order flow, which reflects customer's private short-term information, significantly affect short and medium-term bond yield volatility. Disagreement among customer about short-term information drive short and mediumterm bond yield volatility.

High long-term bond yield volatility is driven by different trading pattern between dealers and customers. Dealers who trade on long-term bond intrinsic value have a different kind of private information compared to customers who try to exploit short-term information. The disagreement between customers and dealer is not about the same private information or its interpretation. They have different private information because they accumulate a different kind of information based on their own investment horizon. Different trading platform and different interpretation of private information between customers and dealer manifest in high long-term bond yield volatility which customers exploit short-term private information, and dealers consider only long-term or strategic issues.

\section{Limitations and suggestions}

To get a comprehensive picture of how bond yield volatility fluctuates around time, we should examine two variable which is not included in this paper: investor sentiment and macroeconomic variables. Changing sentiment among investors may drive bond yield swing. Macroeconomic variables announcement, such as inflation rate and market interest rate, also affect bond yield fluctuate in a considerable predictive direction. Further research needs to examine the effect of sentiment investor and macroeconomic variables announcement to private information accumulation by all market players and, then, also bond yield volatility.

\section{References}

Albuquerque, R. A, \& Vega, C. (2009). Economic news and international stock market co-movement. Review of Finance, 13(3), 401-465. https://doi.org/10.1093/rof/rfn020

Anand, A., \& Subrahmanyam, A. (2008). Information and the Intermediary: Are Market Intermediaries Informed Traders in Electronic Markets? The Journal of Financial and Quantitative Analysis, 43(1), 1-28. https://doi.org/10.2139/ssrn.700864

Andersen, T. G., Bollerslev, T., Diebold, F. X., \& Vega, C. (2007). Real-time price discovery in global stock, bond and foreign exchange markets. Journal of International Economics 73(2): 251-277. https://doi.org/10.1016/j.jinteco.2007.02.004

Back, K., Crotty, K., \& Li, T. (2018). Identifying information asymmetry in securities markets. Review of Financial Studies, 31(6), 2277-2325 https://doi.org/10.1093/rfs/hhx133

Baillie, R. T., Booth, G. G., Tse, Y., \& Zabotina, T. (2002). Price discovery and common factor models. Journal of Financial Markets, 5(3), 309-321. https://doi.org/10.1016/S1386-4181(02)00027-7

Bartolini, L., Goldberg, L. S, \& Sacarny, A. (2008). How economic news moves markets. Current Issues in Economics and Finance, 14(6).

Berger, D., Chaboud, A., \& Hjalmarsson, E. (2009). What drives volatility persistence in the foreign exchange market? Journal of Financial Economics, 94(2), 192-213. https://doi.org/10.1016/j.jfineco.2008.10.006 
Bongaerts, D., De Jong, F., \& Driessen, J. (2017). An asset pricing approach to liquidity effects in corporate bond markets. Review of Financial Studies, 30(4), 1229-1269. https://doi.org/10.1093/rfs/hhx005

Brandt, M. W., \& Kavajecz, K. A. (2004). Price discovery in the U.S. treasury market: The impact of order flow and liquidity on the yield curve. Journal of Finance, 59(6), 2623-2654. https://doi.org/10.1111/j.1540-6261.2004.00711.x

Brenner, M., Pasquariello, P., \& Subrahmanyam, M. (2009). On the volatility and comovement of U.S. financial markets around macroeconomic news announcements. Journal of Financial and Quantitative Analysis, 44(6), 1265-1289. https://doi.org/10.1017/S002210900999038X

Caporale, G. M., \& Girardi, A. (2013). Price discovery and trade fragmentation in a multi-market environment: Evidence from the MTS system. Journal of Banking and Finance, 37(2), 227-240. https://doi.org/10.1016/j.jbankfin.2012.07.027

Cieslak, A., \& Povala, P. (2016). Information in the term structure of yield curve volatility. Journal of Finance, 71(3), 1393-1436. https://doi.org/10.1111/jofi.12388

Collin-Dufresne, P., \& Fos, V. (2015). Do prices reveal the presence of informed trading? Journal of Finance, 70(4), 1555-1582. https://doi.org/10.1111/jofi.12260

Condie, S., \& Ganguli, J. (2017). The pricing effects of ambiguous private information. Journal of Economic Theory. 172, 512-557. https://doi.org/10.1016/j.jet.2017.06.005

Evans, M. D. D., \& Lyons, R. K. (2002). Order flow and exchange rate dynamics. Journal of Political Economy, 110(1), 170-180. https://doi.org/10.1086/324391

Hasbrouck, J. (1991). Measuring the information content of stock trades. The Journal of Finance, 45(10), $179-207$. https://doi.org/10.1111/j.1540-6261.1991.tb03749.x

He, Z., Kelly, B., \& Manela, A. (2017). Intermediary asset pricing: New evidence from many asset classes. Journal of Financial Economics. 126(1), 1-35. https://doi.org/10.1016/j.jfineco.2017.08.002

Kang, W., Ratti, R. A., \& Yoon, K. H. (2015). The impact of oil price shocks on the stock market return and volatility relationship. Journal of International Financial Markets, Institutions and Money, 34, 41-54. https://doi.org/10.1016/j.intfin.2014.11.002

Khalil, S., Mansi, S., Mazboudi, M., \& Zhang, A. (Jianzhong). (2019). Information asymmetry and the wealth appropriation effect in the bond market: Evidence from late disclosures. Journal of Business Research, 95, 49-61. https://doi.org/10.1016/j.jbusres.2018.09.022

Kryzanowski, L., Perrakis, S., \& Zhong, R. (2017). Price discovery in equity and CDS markets. Journal of Financial Markets, 35, 21-46. https://doi.org/10.1016/j.finmar.2017.07.006

Lehmann, B. N. (2002). Some desiderata for the measurement of price discovery across markets. Journal of Financial Markets, 5(3), 259-276. https://doi.org/10.1016/s1386-4181(02)00025-3

Ma, C., Wang, H., Cheng, F., \& Hu, D. (2017). Asset pricing and institutional investors with disagreements. Economic Modelling, 64, 231-248. https://doi.org/10.1016/j.econmod.2017.03.018

Martinez, V., \& Tse, Y. (2018). Intraday price discovery analysis in the foreign exchange market of an emerging economy: Mexico. Research in International Business and Finance, 45, 271-284. https://doi.org/10.1016/j.ribaf.2017.07.159

Menkveld, A. J., Sarkar, A., \& Van Der Wel, M. (2012). Customer order flow, intermediaries, and discovery of the equilibrium risk-free rate. Journal of Financial and Quantitative Analysis, 47(4), 821-849. https://doi.org/10.1017/S0022109012000245 


\section{Private information, yield volatility, and interaction between groups of investors...}

\section{Buddi Wibowo}

O’Hara, M. (2003). Presidential address: Liquidity and price discovery. Journal of Finance, 58(4), 1335-1354. https://doi.org/10.1111/1540-6261.00569

Schreiber, P. S., \& Schwartz, R. A. (2009). Price discovery in securities markets. The Journal of Portfolio Management, 12(4), 43-48. https://doi.org/10.3905/jpm.1986.409071

Valseth, S. (2013). Price discovery in government bond markets. Journal of Financial Markets, 16(1), 127-151. https://doi.org/10.1016/j.finmar.2012.04.005

Westerlund, J., Norkute, M., \& Narayan, P. K. (2015). A factor analytical approach to the efficient futures market hypothesis. Journal of Futures Markets, 35(4), 357-370. https://doi.org/10.1002/fut.21687 